\title{
PReS-FINAL-2125: A Japanese girl with childhood-onset anti-Ku antibody positive generalized morphea-myositis overlap syndrome
}

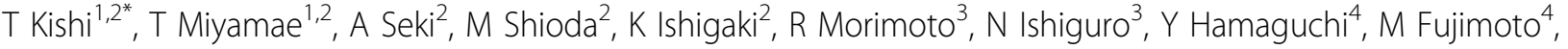 \\ Y Kawaguchi ${ }^{1}$, H Yamanaka', S Nagata ${ }^{2}$
}

From 20th Pediatric Rheumatology European Society (PReS) Congress

Ljubljana, Slovenia. 25-29 September 2013

\section{Introduction}

Anti-Ku antibodies are autoantibodies against the P70/80 DNA-PK activated factor. These antibodies were identified in patients with scleroderma-polymyositis overlap syndrome by Mimori et al., and have subsequently been identified in approximately $1 \%$ of children with overlap syndromes.

\section{Objectives}

We report the case of a Japanese child with anti-Ku antibody positive overlap syndrome.

\section{Methods}

We retrospectively explore the difference between childhood anti-Ku positive syndromes, juvenile dermatomyositis and adult onset anti-Ku positive syndromes.

\section{Results}

The patient, a 16-year-old Japanese girl, first developed symptoms at the age of 7 . Her initial symptoms consisted of multiple brownish plaques on her left forearm that gradually extended to her upper arm, back, and left thigh. She underwent a skin biopsy at the age of 8 that revealed generalized morphea(GM). Laboratory findings included positive anti-nuclear antibody $(1: 1,280)$ and elevated serum creatine kinase (CK, 1,249 U/L) even though she lacked clinical evidence of myositis, myocardial failure or muscular dystrophy. Repeated skin biopsy at the age of 14 revealed lymphocytic infiltrations around vessels and thickened collagen bundles in the dermis. Although she still lacked clinical signs of muscular involvement, MRI demonstrated findings consistent with myositis and bilateral thigh atrophy. Furthermore, serum anti-Ku antibody

Table 1

\begin{tabular}{|c|c|c|c|c|c|c|c|c|c|c|}
\hline & Diagnosis & $\begin{array}{c}\text { Initial } \\
\text { symptom }\end{array}$ & $\begin{array}{l}\text { Age at } \\
\text { onset, } \\
\text { Gender }\end{array}$ & $\begin{array}{c}\text { Observation } \\
\text { period }\end{array}$ & $\begin{array}{c}\text { Raynaud } \\
\text { phenomenon }\end{array}$ & Sclerodactyly & Myositis & $\begin{array}{c}\text { Organ } \\
\text { involvement }\end{array}$ & $\begin{array}{l}\mathrm{CK}(\mathrm{U} / \\
\mathrm{I}) / \\
\text { Ald(U/ } \\
\text { I) }\end{array}$ & ANA \\
\hline $\begin{array}{l}\text { clild } \\
\text { onset }\end{array}$ & GM/PM & Multiple skin lesions & $\begin{array}{c}7 y \\
\text { Female }\end{array}$ & $8 y 6 m$ & - & + & + & - & $\begin{array}{c}1,249 / \\
20.9\end{array}$ & $1: 1,280$ \\
\hline \multirow[t]{3}{*}{$\begin{array}{l}\text { adult } \\
\text { onset }\end{array}$} & $\mathrm{DM}$ & $\begin{array}{c}\text { Muscle weakness, } \\
\text { Weight loss }\end{array}$ & $\begin{array}{c}30 y \\
\text { Female }\end{array}$ & $2 y 2 m$ & + & - & + & IP & $\begin{array}{c}4,699 / \\
53.8 \\
\end{array}$ & $1: 2,560$ \\
\hline & SSc/PM & $\begin{array}{c}\text { Muscle weakness, Joint } \\
\text { pain }\end{array}$ & $\begin{array}{c}32 y \\
\text { Female }\end{array}$ & $12 \mathrm{y} 0 \mathrm{~m}$ & + & + & + & ED & $\begin{array}{c}1,078 / \\
16.6\end{array}$ & $1: 10,240$ \\
\hline & SSc/PM & Arthritis & $\begin{array}{c}46 y \\
\text { Female }\end{array}$ & $4 y 10 m$ & + & + & + & $\begin{array}{l}\text { IP,ED, } \\
\text { Arthritis }\end{array}$ & $\begin{array}{c}1,825 / \\
30.9\end{array}$ & $1: 640$ \\
\hline
\end{tabular}

'Institute of Rheumatology, Tokyo Women's Medical University, Tokyo, Japan Full list of author information is available at the end of the article 
was detected by immunoprecipitation assay. She was thus diagnosed with generalized morphea-polymyositis overlap syndrome. She was treated with methylprednisolone pulse therapy followed by oral glucocorticosteroids which resulted in a gradual decrease in serum CK levels.

Three patients with adult onset anti-Ku antibody syndrome also presented to our institute. All three patients were female, and the average age of onset was 36.0 years old (range 30-46)(Table 1). Each patient was treated with glucocorticosteroids, but immunosuppresnts were ultimately required to suppress disease activity in all three cases.

\section{Conclusion}

Our pediatric patient represents one of the youngest reported cases of anti-Ku antibody positive overlap syndrome. Consistent with previously reported cases, she had remarkably high levels of serum CK despite a lack of muscle weakness. The child had a slowly progressive clinical course with no organ involvement. Further reports are required to fully determine the characteristics of childhood-onset anti-Ku antibody positive overlap syndrome.

\section{Disclosure of interest}

None declared.

\section{Authors' details}

${ }^{1}$ Institute of Rheumatology, Tokyo Women's Medical University, Tokyo, Japan. ${ }^{2}$ Department of Pediatrics, Tokyo Women's Medical University, Tokyo, Japan. ${ }^{3}$ Department of Dermatology, Tokyo Women's Medical University, Tokyo, Japan. ${ }^{4}$ Department of Dermatology, Kanazawa University Graduate School of Medical Science, Ishikawa, Japan.

Published: 5 December 2013
Submit your next manuscript to BioMed Central and take full advantage of:

- Convenient online submission

- Thorough peer review

- No space constraints or color figure charges

- Immediate publication on acceptance

- Inclusion in PubMed, CAS, Scopus and Google Scholar

- Research which is freely available for redistribution

Submit your manuscript at www.biomedcentral.com/submit 